\title{
Belphégor
}

\section{The Secret and Curious Histories of Wonder Woman \& Wonder Woman, a multiple book review:}

\section{Chris Reyns-Chikuma}

\section{(2) OpenEdition}

1 Journals

\section{Electronic version}

URL: http://journals.openedition.org/belphegor/722

DOI: 10.4000/belphegor.722

ISSN: 1499-7185

Publisher

LPCM

\section{Electronic reference}

Chris Reyns-Chikuma, "The Secret and Curious Histories of Wonder Woman \& Wonder Woman, a multiple book review: », Belphégor [Online], 14 | 2016, Online since 10 October 2016, connection on 23 September 2020. URL : http://journals.openedition.org/belphegor/722 ; DOI : https://doi.org/10.4000/ belphegor.722

This text was automatically generated on 23 September 2020 .

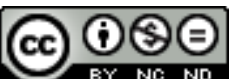

Belphégor est mis à disposition selon les termes de la Licence Creative Commons Attribution - Pas d'Utilisation Commerciale - Pas de Modification 4.0 International. 


\section{The Secret and Curious Histories of Wonder Woman \& Wonder Woman, a multiple book review:}

Chris Reyns-Chikuma

\section{REFERENCES}

-Wonder Woman Unbound, Chicago Review Press, 2014, by Tim Hanley;

-The Secret History of Wonder Woman, New York: A. Knopf, 2014, by Jill Lepore;

-Wonder Woman, Bondage and Feminism in the Marston/Peter Comics 1941-48, Rutgers U.P., 2015, by Noah Berlatsky

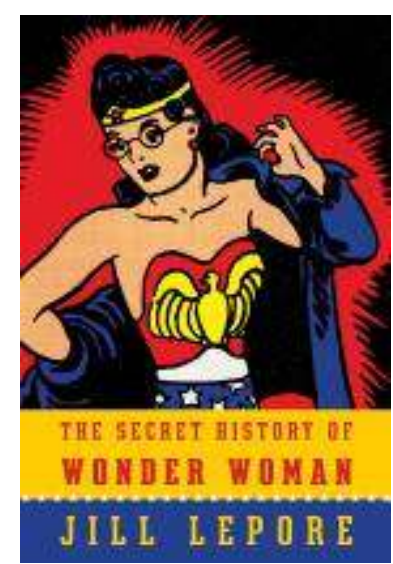




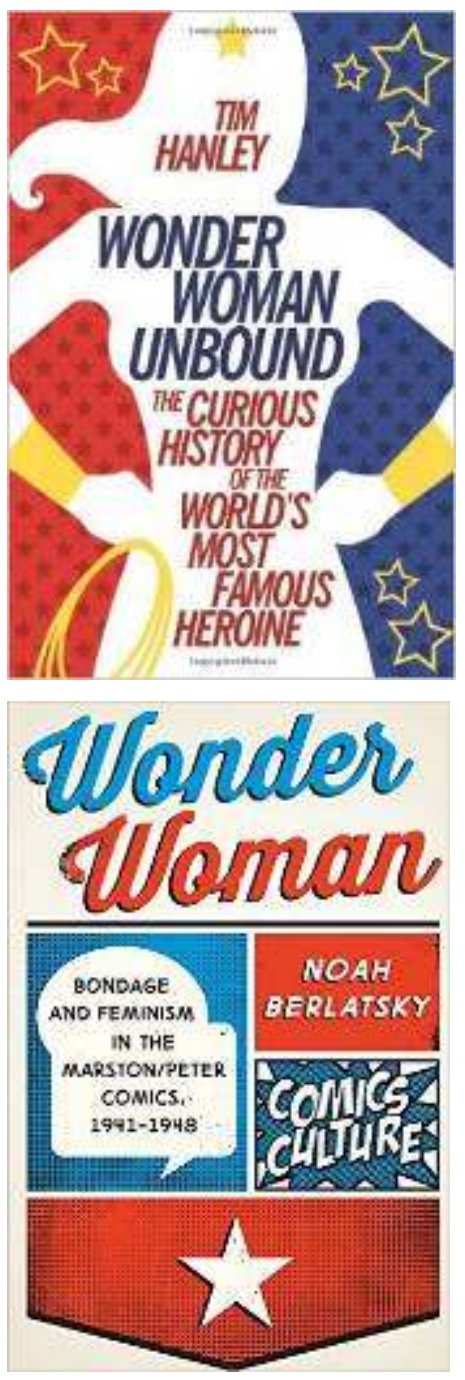

1 Any search for references on "Wonder Woman $»^{1}$ would show hundreds of articles but only 3 or 4 «serious » books. After the brief, yet forerunning, references in Trina Robbins's various books on Women and Comics's, in 2000, Les Daniels, one of the greatest fans-specialists of comics, published Wonder Woman, the Complete History (San Francisco Chronicle Books). Although the text is interesting, Daniels' book is first and foremost useful for its many gorgeous illustrations. The text is relatively short compared to the number of pages ( $1 / 4$ of the 200 pages). When published, it contained some new information about WW, but it would be now considered a good introductory summary with excellent pics. It covers a long period from its very beginning, 1942, to 2001 (overleaf: Painting by Alex Ross for «Wonder Woman, Strength of Will », p. 201). This is a very useful and beautiful book to have in your library containing many visual documents (from the comics of all periods of course but also from TV series, movies, advertising, tie-ins), organized by periods and themes, with precise legends, that are not always easy to find even in the Age of internet. The distinction between Wonder Woman (the comics) and Wonder Woman (the icon) found in Daniels' work is a pertinent one since most of the books and articles are about the icon rather than the comics itself as emphasized also by Berlatsky (see the last part of this book review).

In 2003, Lilian Robinson, principal of the Simone de Beauvoir Institute at Concordia University in Montreal, published Wonder Woman: Feminisms and Superheroes (Routledge, 
140 pages). Beyond its eclecticism (mixing references to canonical works from Ariosto up to De Lillo, including some feminist contemporary texts like Kingston's The Woman Warrior, Ensler's The Vagina Monologues, Erbert's Ludic Feminism and After, and Butler's Gender Trouble), its main interest is in its conciseness about ideological, and mostly feminist issues. On the other hand, it contains no picture which shows that it is not really about $W W$ the comics per se.

In 2009, Mike Madrid, creative director at Exterminating Angel Press, wrote The Supergirls: Fashion, Feminism, and the History of Comic Book Heroines. As the title reveals, the book is not only about WW, but about many superheroines from their beginning (before WWII) to those one can see nowadays on TV and at the movies. There are no picture and no picture analysis in his study. This is because it may not be necessary since it is a general, sometimes too broad, cultural history based on an ideological and political analysis of female icons. This includes feminist questions such as the eroticization and deification of female superheroes. Although a very valuable reading The Supergirls is really related to the $W W$ comics.

The most recent books were published in 2014 and 2015. Wonder Woman Unbound, the Curious History of the World's Most Famous Heroine (April 2014, 300 pages) was written by Tim Hanley, a comic book historian without university affiliation. Three months later, a book came out which was largely discussed on blogs and very positively reviewed in general and in specialized venues. Entitled The Secret History of Wonder Woman (October 2014, 370 pages), it was written by Jill Lepore, a professor of American History at Harvard. There are three main differences between these two studies: their writing style, their methodological approach and the period covered. The first difference is that Hanley's book goes beyond the period covered by Lepore. While Hanley's is divided in three relatively even parts (with 80 pages each), covering the traditional three periods, the golden, silver, and bronze Ages, Lepore's covers mainly the golden Age but she also goes back extensively to the preceding period from the beginning of the 20th century to the 1930s. This is because, although they seem to have the same goal and similar conclusions - namely connecting feminist debate with the WW comics and icon - they do it in a different way. Using different methodological approaches, Hanley's study is more of a sociological study based on a " text-image " analysis while Lepore's is typically a historical study going back to the past to explain the present. Hanley uses statistics about interesting topics like the number of bondage scenes with detailed charts and systematic comparisons of WW with other superheroes' characteristics (their origin, their connections to other characters, etc.). Consequently, while Lepore's book reads very much like a story inscribed within a long history of feminist struggles and secret or unknown stories of real people/women, Hanley's reads less as a narrative. Both cover very similar topics and come to similar conclusions, however, there are also some significant differences. For instance, Hanley's bondage chapter is the longest of the book and much longer than Lepore's chapter on the same topic (entitled "Suffering Sappho! », p. 231-46=15p.). The word "bondage" is not even mentioned in Lepore's index. Surprisingly, Marston explained to Gaines, his publisher, that bondage scenes were a way to teach the value of submission to everybody, particularly to boys. This is likely the most troublesome element in WW, since, as shown with stats and charts, most of these scenes involve women and not boys/men. For example, Hanley states that the bondage scenes represent almost $25 \%$ of the images of $\mathrm{WW}$, and when compared to Marvel superheroes in similar scenes, he found a maximum of only $15 \%$. In Wonder Woman: The Complete Newspaper Strip: 1944-1945 (2014), one can see such a scene of 
"bondage" where WW accepts to be tied with chains and ropes as part of a Houdini's style event. Of course, this scene could be understood as a feminist challenge to the typical escapist show of that time since escapology was a field only occupied by men. However, many other scenes are more ambiguous.

5 Also while Lepore does present Marston as a charlatan (132) and a huckster (156) and a «duke of deception » (161), and even as a tyrannical man (223), Hanley presents him rather as a psychologist with false, essentialist but interesting interpretations about the goodness of women. Based more on his belief than on the results of his research (that he did not often do in a conventional academic way), this interpretation is encapsulated in his DISC theory, which refers to Dominance, Inducement, Submission, and Compliance. According to him, positive relationships were based on inducing submission. Hanley summarizes it as: «Harsh dominance led to forced compliance, while kind inducement led to willing submission. » (15). Marston's obsession with the lie detector (a machine that he largely contributed to invent and popularize), is also questionable, since he himself lied a lot and recommended that women fake their feelings (see Hanley, 53). Hence, WW's famous "golden lasso", which is part of the bondage apparatus, could be seen as a metaphor for the lie detector. In the very first stories the lasso was supposed to force WW's captives to simply obey but in the following stories, it was to induce him/her to tell the truth (like the lie detector). Alternatively, according to Marston, the lasso could also be seen as a metaphor for the feminine sex that can ensnare men and therefore women should take advantage of it to impose their loving way. Hanley's study provides much information that situates WW within the comics world comparing her positive myth of origin with other superheroes' myth of origin, often negative (i.e., Wayne became Batman because he witnessed the death of his parents). Surprisingly, even though Hanley is a comic book historian who wrote mostly for online blogs and websites, his methodology, closer to the social sciences, impacted his writing style which consists mostly of explaining his quantitative findings. Without the traditional academic endnotes and with few but very informative footnotes (such as for example the one p. 48 that questions also the complicity of the two women), this is a very useful book for scholars and educated fans.

6 On the other hand, while Lepore is a researcher in history of the highest standard (Harvard), her book tells Her-story in a non-academic way mixing the style of The New Yorker, for which she is also a staff writer, with the traditional academic endnotes containing the bibliographical references (70 pages) and a good index (17 pages). This makes it a rich and dense but also very compelling narrative for educated readers. The " secret » of the title refers to all the unknown her-stories that largely explain how one man could create such a powerful feminist icon. Marston was certainly a "genius" with a very unusual background for a comic book creator. He was a member of the WASP elite with several degrees from Harvard (Law, Psychology) while many other creators were from lower-middle classes holding only a high school degree and mainly of Jewish origins. He also wrote a pulp soft-porn historical novel (Venus with Us) and several "scientific" essays (i.e., Emotions of Normal People). That said, the richness and success of WW (the comics and the icon) are also due to the fact that Marston was surrounded and preceded by many women who contributed to feminist history, from the hungerstriking suffragettes to his polyamorous female partners. Elizabeth Holloway, who was his first partner, was the main income earner since Marston could not keep a stable job (which also explains the time he had to create WW). His second partner, Olive Byrne, took care of the four kids he had with her and Elizabeth. Lepore's title refers also to the 
secret the three of them kept: "Marston, Holloway, and Byrne had led a secret, closeted life. It had its costs » (272). Lepore concludes that cost is not only or even mainly about WW, but about the impact of this secret on their children, their family and close friends and more broadly on many women and society. Lepore then writes: « one tragedy of feminism in the twentieth century was the way its history seemed to be forever disappearing. [...] Alice Paul [the American suffragist and feminist-1885-1977] brought her visitors into her parlor, where the walls were covered with oil portraits of suffragists. When she asked them to identify the women in those portraits, they couldn't name a single one " (293). Lepore's book is rich and well-written and also, which is rarer for a book coming from an academic, it is a touching study. Unfortunately, even though she has written several books on American history (two of which were finalists for the Pulitzer Prize), she has never before written on comics. Hence, her Harvardian high culture position and radical feminist agenda might sometimes blind her a bit on popular culture, including comics. That is what comic book creator, Willow Wilson, seems to imply in her response on her blog to a New Yorker op-ed article of MAY 7, 2015 entitled "Looking at Female Superheroes with Ten-YearOld Boys," criticizing Wilson's last comics series, A Force:

7 "So I was the last person on the internet to find out about this little op-ed by Jill Lepore. When Harvard professors are throwing shade on you from the rarified heights of the New Yorker, you have officially arrived in life, or at least in comics. [...] Her article is a very crisp demonstration of the difference between criticism from within the community-criticism from people who love comics and want to see them succeed-and criticism from the self-appointed gatekeepers of art and culture, who categorically do not give a shit. [...] What I don't understand is why someone in her position would, from her perch a thousand feet up in the ivory tower, take pot shots at those of us who are in the trenches, doing exactly that $»^{3}$.

8 This disdain or un-empathy from scholars is actually very common. As Noah Berlatsky, the author of the last book we are going to briefly review here, writes: «It is not just the public that tends to focus on Wonder Woman [the icon] rather than Wonder Woman [the comics]. It is the scholars as well. There is remarkably little criticism that sees Wonder Woman as an aesthetically important or significant comic in its own right. » (4). Strangely, this is also what Berlatsky's critical perspective is: "[my] book quite consciously privileges theory' over comics' specific history.» (5) His book is about gender and the way bondage is playing an emancipatory role in Marston's life and comics. Interestingly enough, after giving a summary of Marston's life (already explained by most critics and cited above), he gave a short biography of the artist, Harry Peter, and of other male creators, which is something rarely done. Furthermore, he demonstrates in very detailed arguments and examples how Marston and Peter produced a comic series that is beautifully feminist, pacifist and queer. Berlatsky shows how many Post-Marston WW stories are either insipid (from the TV show with Carpenter to many contemporary versions), or patriarchal-chauvinist and antifeminist (Azzarello/Chang), with few exceptions (Gail Simone to a large extent). He concludes stating: «My fondest hope for this book is that it encourages some people, whether Wonder Woman fans or otherwise, to go back and read those original comics. » (215)

Will we have a reissue of the Marston/Peter Wonder Woman comics other than the not very accessible DC Archive published in 2013? How much longer will we have to wait for a (scholarly) book that is going to concentrate on the aesthetics of Wonder Woman? 
Will the new movie by Canadian Michelle McLaren as director, due in 2017, help bring a closer look at the comics themselves?

\section{NOTES}

1. "Wonder Woman" is now WW.

2. The last one has a more substantial development on Wonder Woman in The Great Women Superheroes - Kitchen Sink, 1997.

3. http://gwillowwilson.com/post/118822887543/dr-lepores-lament 